\title{
Parainfluenza virus infections
}

\author{
SuZANNe K. R. Clarke
}

Public Health Laboratory, Myrtle Road, Kingsdown, Bristol BS2 8EL

\begin{abstract}
Summary
Parainfluenza viruses types 1, 2 and 3 were found in $2.5 \%, 0.8 \%$ and $1.6 \%$ respectively of patients examined in the MRC/PHLS general practice survey and in $2.2 \%, 0.7 \%$ and $2.7 \%$ of those in the hospital survey. Type 3 infections were found earlier in life than type 1, while type 2 infections tended to be detected in older children. These viruses were found most frequently in croup and laryngitis but were also common causes of coryza and lower respiratory infections, especially in general practice. The epidemiology and diagnosis of parainfluenza virus infections are discussed briefly.
\end{abstract}

Since they were first described in 1958, the parainfluenza viruses have been shown to be associated with acute respiratory disease, especially croup in children under 4 years old. This was found in surveys in this country in general practice by Banatvala, Anderson \& Reiss (1964), the M.R.C. Working Party on Acute Respiratory Virus Infections (1965) and Hope-Simpson \& Higgins (1969), and among children in hospital by Holzel et al. (1965) and Gardner et al. (1971), and in comparable studies in the U.S.A. in the general population by Monto \& Cavallaro (1971), and among children in hospital by Chanock et al. (1963).

\section{Results of MRC/PHLS surveys}

Overall, parainfluenza virus type 1 was isolated from $2.5 \%$, type 2 from $0.8 \%$, and type 3 from $1.6 \%$ of the 3966 patients in the survey in general practice, and type 1 was isolated from $2.2 \%$, type 2 from $0.7 \%$, type 3 from $2 \cdot 7 \%$ and type 4 from one of the 2418 children in the hospital survey.

\section{Season}

Isolation rates for parainfluenza types 1 and 3 by time for both surveys are shown in Figs. 1 and 2 (see Poole \& Tobin, this symposium). Epidemics of type 1 occurred in the winters of 1964-65 and 1966-67 with peaks in October-November, but not in the winter of 1965-66. The first epidemic appeared to end sooner in some practices than others, and the second started several months earlier in Scotland and the North of England than the South of the country.
Parainfluenza virus type 3 was isolated continuously in general practice from small local epidemics which were not synchronous in different areas. Among children in hospital parainfluenza 3 was isolated particularly between May and July.

\section{Age}

Isolation rates by age for both surveys are shown in Table 1. Although infection was common between the ages of 1 and 4 years, there was some difference between the types. Infection with parainfluenza type 3 occurred earliest, often under 6 months of age. Type 1 infections occurred later, rarely under 6 months, and usually between 1 and 4 years of age. Type 2 infections occurred latest, often between and 14 years of age.

\section{Diagnosis}

Isolation rates by diagnosis are shown in Table 2. Parainfluenza viruses were isolated from 12-22\% of patients with croup and laryngitis and about $6 \%$ of patients with common colds in both studies. They were isolated from $5-7 \%$ of patients with tracheitis, bronchitis, bronchiolitis, pneumonia, and influenza in general practice, but from a smaller proportion of children in hospital with these conditions. They were isolated only rarely from patients with primary otitis media and then were usually type 3 . There was little difference between the types except that type 2 was isolated less frequently in all conditions. Type 1 was found more frequently in croup than type 3 , and type 3 was found more frequently in bronchitis, bronchiolitis and pneumonia than type 1 .

Isolation rates for all parainfluenza virus types by diagnosis and age are shown for the surveys in Figs. 3 and 4 (Poole \& Tobin, this symposium). There was little difference at different ages among children in hospital, except that parainfluenza viruses were found more often among children aged 1-4 years with common colds and pharyngitis than among older children with these conditions.

In general practice, parainfluenza viruses were found in common colds, croup and tracheitis more frequently in children under 15 years than in adults. In bronchitis and influenza they were found more frequently in children under 4 than over 4 years. 
TABLE 1. Parainfluenza virus isolation rates (\%) by age

\begin{tabular}{|c|c|c|c|c|c|c|c|c|}
\hline \multirow[b]{2}{*}{ Hospital } & $\begin{array}{l}\text { No. } \\
\text { isolated }\end{array}$ & $\begin{array}{l}\text { Isolation } \\
\text { rate }\end{array}$ & $\begin{array}{l}\text { No. } \\
\text { isolated }\end{array}$ & $\begin{array}{l}\text { Isolation } \\
\text { rate }\end{array}$ & $\begin{array}{c}\text { No. } \\
\text { isolated }\end{array}$ & $\begin{array}{l}\text { Isolation } \\
\text { rate }\end{array}$ & $\begin{array}{c}\text { No. } \\
\text { isolated }\end{array}$ & $\begin{array}{l}\text { Isolation } \\
\text { rate }\end{array}$ \\
\hline & \multicolumn{2}{|c|}{ 0-5 months } & \multicolumn{2}{|c|}{ 6-11 months } & \multicolumn{2}{|c|}{$1-4$ years } & \multicolumn{2}{|c|}{$5-14$ years } \\
\hline $\begin{array}{l}\text { Parainfluenza } \\
\text { type } 1 \\
\text { type } 2 \\
\text { type } 3\end{array}$ & $\begin{array}{r}3 \\
2 \\
20\end{array}$ & $\begin{array}{l}0 \cdot 4 \\
0 \cdot 3 \\
2 \cdot 9\end{array}$ & $\begin{array}{l}5 \\
5 \\
8\end{array}$ & $\begin{array}{l}1 \cdot 3 \\
1 \cdot 3 \\
2 \cdot 1\end{array}$ & $\begin{array}{r}42 \\
6 \\
34\end{array}$ & $\begin{array}{l}3 \cdot 9 \\
0 \cdot 6 \\
3 \cdot 2\end{array}$ & $\begin{array}{l}3 \\
5 \\
4\end{array}$ & $\begin{array}{l}1 \cdot 0 \\
1 \cdot 7 \\
1 \cdot 4\end{array}$ \\
\hline Total & 25 & $3 \cdot 7$ & 18 & $4 \cdot 8$ & 82 & $7 \cdot 6$ & 12 & $4 \cdot 2$ \\
\hline No. of specimens tested & 682 & & 374 & & 1075 & & 287 & \\
\hline General practice & \multicolumn{2}{|c|}{$0-4$ years } & \multicolumn{2}{|c|}{ 5-14 years } & \multicolumn{2}{|c|}{ 15-44 years } & \multicolumn{2}{|c|}{$45+$ years } \\
\hline $\begin{array}{r}\text { Parainfluenza } \\
\text { type } 1 \\
\text { type } 2 \\
\text { type } 3\end{array}$ & $\begin{array}{r}41 \\
5 \\
26\end{array}$ & $\begin{array}{l}4 \cdot 2 \\
0 \cdot 5 \\
2 \cdot 6\end{array}$ & $\begin{array}{l}32 \\
14 \\
17\end{array}$ & $\begin{array}{l}3 \cdot 0 \\
1 \cdot 3 \\
1 \cdot 6\end{array}$ & $\begin{array}{r}15 \\
6 \\
10\end{array}$ & $\begin{array}{l}1 \cdot 2 \\
0,5 \\
0 \cdot 8\end{array}$ & $\begin{array}{r}10 \\
6 \\
10\end{array}$ & $\begin{array}{l}1 \cdot 5 \\
0.9 \\
1 \cdot 5\end{array}$ \\
\hline Total & 72 & $7 \cdot 3$ & 63 & $6 \cdot 0$ & 31 & $2 \cdot 5$ & 26 & $3 \cdot 9$ \\
\hline No. of specimens tested & 985 & & 1060 & & 1249 & & 672 & \\
\hline
\end{tabular}

\section{Clinical features}

In hospital most strains of parainfluenza virus were isolated from children aged 1-4 with croup. $67 \%$ of parainfluenza type 2 viruses were isolated from children with croup.

Individual clinical features found in more than $30 \%$ of children with parainfluenza infections in hospital are shown in Table 3. The majority had upper respiratory infections. Between a third and a half of infants had lower respiratory infections. Dyspnoea, wheezing, rhonchi and rales were frequent. Parainfluenza viruses were the predominant cause of stridor.

In general practice most strains $(14 \%)$ of parainfluenza viruses were isolated from children under 4 with common colds.

The clinical features found in more than $30 \%$ of patients with parainfluenza infections in general practice are shown in Table 4. Type 1 was usually associated with a febrile coryza and cough, with hoarseness in about half the cases. Many older children had sore throat and headache. Coryza, sore throat and cough were the commonest features in adults and some had an influenza-like illness. Hoarseness was a particular feature of type 1 infections. Type 2 in children aged 5-14 caused an illness similar to that caused by type 1 , but without hoarseness. In adults the picture was of fever with cough in most cases and frequently sore throat, hoarseness and influenza-like symptoms. Type 3 infections in young children gave rise to cough and coryza, sometimes with fever. In older children and adults the picture was similar to type 1 infections.

\section{Laboratory findings}

Monkey kidney tissue culture was the best cell line for the isolation of all the parainfluenza viruses (see Table 3, Poole \& Tobin, this symposium).
The isolation of type 1 seemed unaffected by the day of swabbing within the first 5 days, but types 2 and 3 were isolated most frequently early in the illness.

\section{Discussion}

That parainfluenza type 1 epidemics occur every 2 years and parainfluenza type 3 infections occur every year was shown in these MRC/PHLS surveys and was noted by Tobin (1968) and the PHLS (1973) in this country and by Glezen et al. (1971) in the U.S.A. This is demonstrated in Fig. 1, which shows the parainfluenza virus isolations from all sources (mostly children in hospital) by the Bristol Public Health Laboratory for 11 years from 1962 to 1972 (excluding the small number of parainfluenza type 4 isolations). Although the numbers of parainfluenza type 2 isolations are small, there is a suggestion that type 2 , like type 1 , occurs every 2 years during the same winters as type 1 .

In the MRC/PHLS surveys the peak of the type 1 epidemics in 1964 and 1966 occurred in October and November, at about the same time as the 1962, 1964, 1966, 1968, 1970 and 1972 epidemics in Bristol (Fig. 1). This was the time of the peaks of the epidemics in the U.S.A. in 1964, 1966 and 1968 described by Glezen et al. (1971).

That infections with parainfluenza type 3 occur at a younger age than those with type 1 and that, on the whole, infections with type 1 occur earlier than those with type 2 as shown by the MRC/PHLS surveys, has been demonstrated by serological surveys in this country (Stark, Heath \& Peto, 1964) and in the U.S.A. (Chanock et al., 1963). This is probably because type 3 is more infectious than types 1 and 2, as shown by spread in nursery outbreaks (Chanock et al., 1963). In the MRC/PHLS survey in hospital, infections under 6 months of age occurred frequently with type 3 but rarely with types 1 and 2 . This has also been shown by Mufson et al. (1970) and 


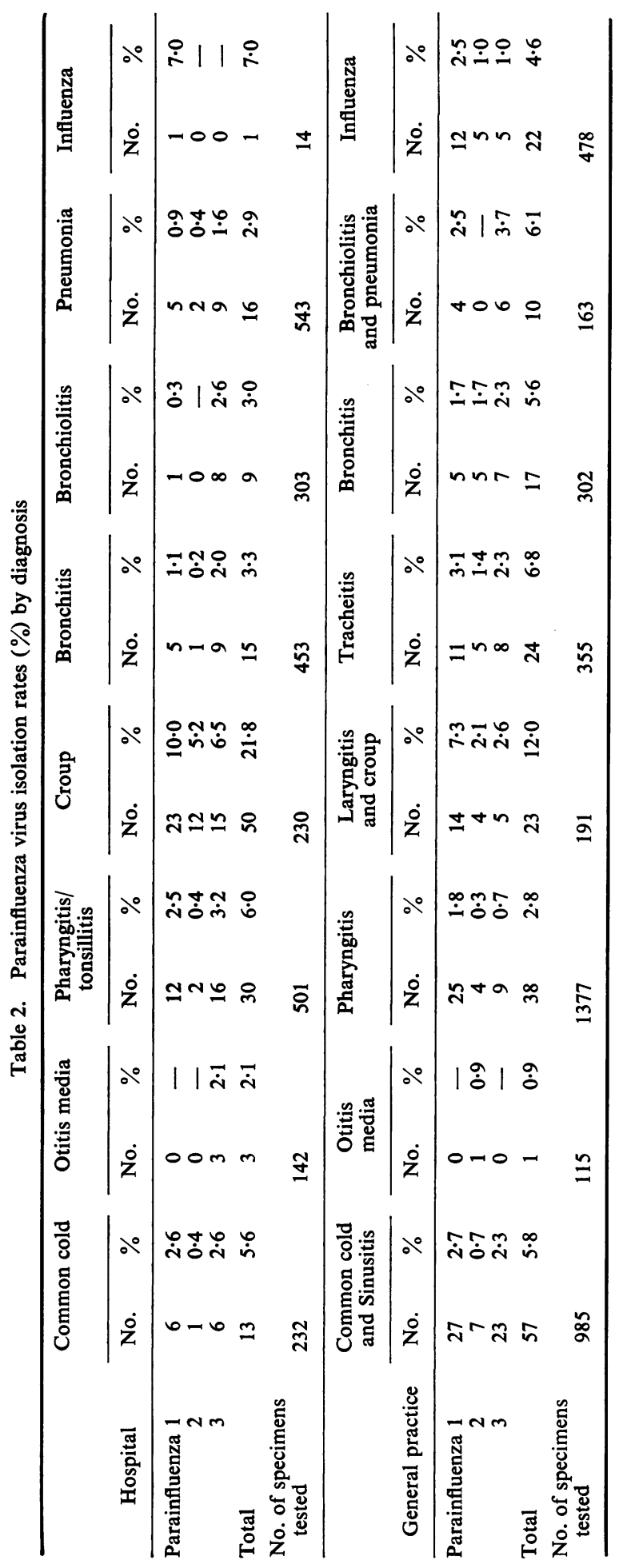


TABLE 3. Percentage of frequent clinical features $(>30 \%)$ in parainfluenza infections: hospital survey

\begin{tabular}{|c|c|c|c|c|c|c|c|c|}
\hline & \multicolumn{3}{|c|}{ Type 1} & \multirow{2}{*}{$\begin{array}{l}\text { Type } 2 \\
\text { Total } \\
0-15 \\
\text { years }\end{array}$} & \multicolumn{3}{|c|}{ Type 3} & \multirow{2}{*}{$\begin{array}{l}\begin{array}{c}\text { Types } \\
2 \text { and }\end{array} \\
\text { Total } \\
0-15 \\
\text { years }\end{array}$} \\
\hline & $\begin{array}{l}<1 \\
\text { year }\end{array}$ & $\begin{array}{l}1-4 \\
\text { years }\end{array}$ & $\begin{array}{l}\text { Total } \\
0-15 \\
\text { years }\end{array}$ & & $\begin{array}{c}<1 \\
\text { years }\end{array}$ & $\begin{array}{c}1-4 \\
\text { years }\end{array}$ & $\begin{array}{l}\text { Total } \\
0-15 \\
\text { years }\end{array}$ & \\
\hline No. of isolations & 10 & 43 & 56 & 19 & 33 & 35 & 72 & 147 \\
\hline $\begin{array}{l}\text { Cough } \\
\text { Fever } \\
\text { Red pharynx } \\
\text { Dyspnoea } \\
\text { Stridor } \\
\text { Vomiting } \\
\text { Rhonchi } \\
\text { Wheezing } \\
\text { Chest recession } \\
\text { Hoarseness } \\
\text { Rales } \\
\text { Convulsions } \\
\text { Red drums } \\
\text { X-ray shadows }\end{array}$ & $\begin{array}{l}90 \\
80 \\
60 \\
60 \\
40 \\
60 \\
40 \\
50 \\
30 \\
40\end{array}$ & $\begin{array}{l}81 \\
81 \\
77 \\
39 \\
44 \\
35\end{array}$ & $\begin{array}{l}84 \\
79 \\
71 \\
45 \\
43 \\
37\end{array}$ & $\begin{array}{l}79 \\
84 \\
63 \\
53 \\
68 \\
\\
53 \\
37 \\
47 \\
32\end{array}$ & $\begin{array}{l}94 \\
76 \\
61 \\
45 \\
\\
42 \\
42 \\
48 \\
36 \\
42\end{array}$ & $\begin{array}{l}77 \\
83 \\
71 \\
\\
37 \\
34\end{array}$ & $\begin{array}{l}85 \\
81 \\
65 \\
37 \\
\\
36 \\
36 \\
35\end{array}$ & $\begin{array}{l}85 \\
80 \\
62 \\
42 \\
36 \\
35 \\
33 \\
32 \\
31 \\
25 \\
21 \\
20 \\
18 \\
14\end{array}$ \\
\hline
\end{tabular}

TABLE 4. Percentage of frequent clinical features $(>30 \%)$ in parainfluenza infections: general practice survey

\begin{tabular}{|c|c|c|c|c|c|c|c|c|c|c|c|c|}
\hline & \multicolumn{5}{|c|}{ Type 1} & \multicolumn{2}{|c|}{ Type 2} & \multicolumn{5}{|c|}{ Type 3} \\
\hline & $\begin{array}{c}0-4 \\
\text { years }\end{array}$ & $\begin{array}{l}5-14 \\
\text { years }\end{array}$ & $\begin{array}{l}15-44 \\
\text { years }\end{array}$ & $\begin{array}{l}45+ \\
\text { years }\end{array}$ & $\begin{array}{l}\text { Total } \\
0-45+ \\
\text { years }\end{array}$ & $\begin{array}{r}5-14 \\
\text { years }\end{array}$ & $\begin{array}{c}15+ \\
\text { years }\end{array}$ & $\begin{array}{c}0-4 \\
\text { years }\end{array}$ & $\begin{array}{r}5-14 \\
\text { years }\end{array}$ & $\begin{array}{l}15-44 \\
\text { years }\end{array}$ & $\begin{array}{c}45+ \\
\text { years }\end{array}$ & $\begin{array}{c}\text { Total } \\
0-45+ \\
\text { years }\end{array}$ \\
\hline No. of isolations & 41 & 32 & 15 & 10 & 98 & 14 & 12 & 27 & 19 & 10 & 10 & 66 \\
\hline $\begin{array}{l}\text { Cough } \\
\text { Coryza } \\
\text { Fever } \\
\text { Sore throat } \\
\text { Hoarse } \\
\text { Headache } \\
\text { General aches } \\
\text { Glands } \\
\text { Prostration }\end{array}$ & $\begin{array}{l}85 \\
78 \\
68 \\
\\
44\end{array}$ & $\begin{array}{l}87 \\
69 \\
81 \\
59 \\
50 \\
53\end{array}$ & $\begin{array}{l}53 \\
47 \\
33 \\
60\end{array}$ & $\begin{array}{l}80 \\
70 \\
60 \\
60 \\
60 \\
50 \\
50 \\
\\
40\end{array}$ & $\begin{array}{l}81 \\
69 \\
66 \\
46 \\
42\end{array}$ & $\begin{array}{l}79 \\
57 \\
93 \\
57 \\
50 \\
\\
36\end{array}$ & $\begin{array}{l}75 \\
33 \\
75 \\
58 \\
42 \\
58 \\
75\end{array}$ & $\begin{array}{l}96 \\
81 \\
37\end{array}$ & $\begin{array}{l}74 \\
53 \\
79 \\
52 \\
42 \\
47\end{array}$ & $\begin{array}{l}60 \\
90 \\
60 \\
60 \\
\\
50\end{array}$ & $\begin{array}{r}100 \\
70 \\
70 \\
\\
40\end{array}$ & $\begin{array}{l}85 \\
73 \\
58 \\
36\end{array}$ \\
\hline
\end{tabular}

Gardner et al. (1971). This is probably due to the relative infectivities of the three types and not because parainfluenza type 3 is able to infect in the presence of maternal antibody, for Zakstelskaya, Arnaudova \& Yakhno (1969) showed that parainfluenza infections occurred only in babies who had lost their maternal antibodies.

In the MRC/PHLS survey in hospital, parainfluenza type 1 was isolated from significantly more children with respiratory disease $(4.6 \%$ of 648$)$ than from those without respiratory illness $(1.4 \%$ of 280$)$ $(P<0.05)$. Type 3 was isolated from more children with respiratory disease $(2.8 \%$ of 648$)$ than without $(1.4 \%$ of 280$)$, though the difference was not statistically significant. Similar results were found in the previous MRC survey (1965). This is evidence that the parainfluenza viruses cause respiratory ill- ness in children. That they cause such illness in adults has been shown in volunteers experiments (Tyrrell et al., 1959; Taylor-Robinson \& Bynoe, 1963).

In the MRC/PHLS hospital survey, parainfluenza type 3 was isolated from two of the twenty-two children who died with respiratory illnesses, one aged 3 months with cystic fibrosis and an infection of the lungs with proteus species and Pseudomonas pyocyanea, and the other aged 2 months without any contributory cause of death. Deaths associated with parainfluenza infections have been described by Brandt et al. (1970) and the PHLS (1973). Of 377 babies under 12 months old admitted to hospital in Bristol with respiratory infections during two winters and studied virologically, twelve died, and from one parainfluenza type 3 was isolated (Jacobs et al., 


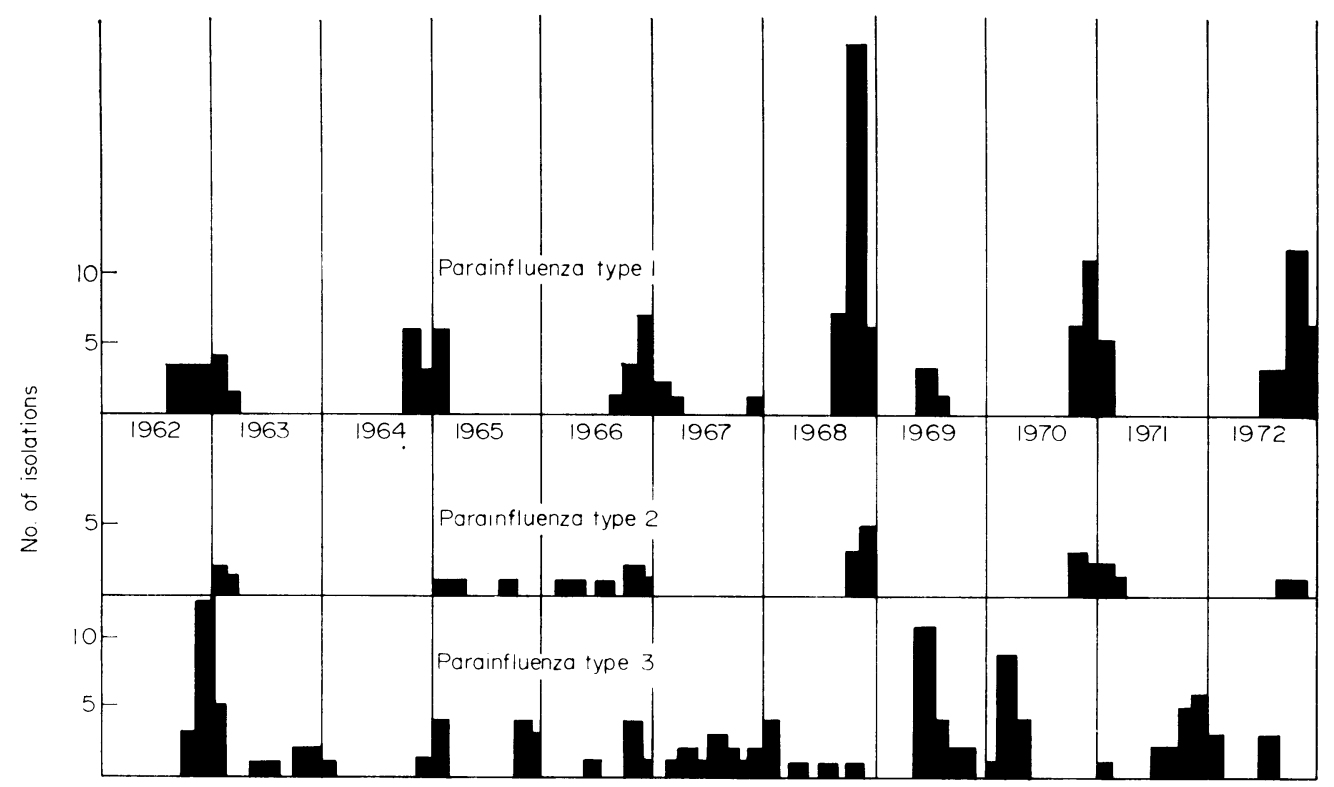

FIG. 1. Isolations of parainfluenza viruses by Bristol Public Health Laboratory, 1962-72.

1971). So deaths due to parainfluenza viruses are probably relatively rare.

Parainfluenza type 4 was isolated only once in the MRC/PHLS surveys. It is as common as the other types according to serological surveys (Gardner, 1969), and causes a similar illness in volunteers (Tyrrell \& Bynoe, 1969). However, like parainfluenza type 2, it grows slowly in tissue culture and this may explain why it is rarely isolated.

Recently, immunofluorescence has been found to be useful in the diagnosis of parainfluenza infections, both by direct examination of respiratory secretions from patients and in the rapid identification of isolates by examination of tissue cultures as soon as haemadsorption occurs (D'Alessio, Williams \& Dick, 1970; Fedová et al., 1971; Gardner et al., 1971).

\section{References}

Banatyala, J.E., Anderson, T.B. \& Reiss, B.B. (1964) Parainfluenza infections in the community. British Medical Journal, 1, 537.

Brandt, C. D., Patrick, J.R., Chandra, R. \& Parrott, R.H. (1970) Infectious agents from cases of sudden infant death syndrome and from members of their community. Clinical Proceedings of the Children's Hospital, D.C. 26, 249.

Chanock, R.M., Parrott, R.H., Johnson, K.M., Kapikian, A.Z. \& BeLL, J.A. (1963) Myxoviruses: parainfluenza. American Review of Respiratory Diseases, 88, 2, 152.

D'Alessio, D., Williams, S. \& Dick, E.C. (1970) Rapid detection and identification of respiratory viruses by direct immunofluorescence. Applied Microbiology, 20, 233.
Fedová, D., Pečenková-Plachtová, I., TUmová, B. \& BRŮČKovÁ, M. (1971) Application of the fluorescent anti- $\bigcirc$ body method in the diagnosis of $M$. parainfluenzae. III. Isclation and identification of $\mathbf{M}$. parainfluenzae on monkey kidney tissue cultures and in nasal and nasopharyngeal swabs. Journal of Hygiene, Epidemiology, Microbiology and Immunology, 15, 82.

GARDNER, S.D. (1969) The isolation of parainfluenza 4 subtypes A and B in England and serological studies of their prevalence. Journal of Hygiene, 67, 545.

Gardner, P.S., McQuillin, J., McGuckin, R. \& DitchBURN, R.K. (1971) Observations on clinical and immunofluorescent diagnosis of parainfluenza virus infections. British Medical Journal, 2, 7.

Glezen, W.P., Loda, F.A., Clyde, W.A., JR, Senior, R.J., Sheaffer, C.I., Conley, W.G. \& DenNy, F.W. (1971) Epidemiologic patterns of acute lower respiratory disease of children in a pediatric group practice. Journal of Pediatrics, 78, 397.

Holzel, A., Parker, L., Patterson, W.H., Cartmel, D., White, L.L.R., Purdy, R., Thompson, K.M. \& Tobin, J.O'H. (1965) Virus isolations from throats of children admitted to hospital with respiratory and other diseases, Manchester, 1962-4. British Medical Journal, 1, 614.

Hope-Simpson, R.E. \& Higgins, P.G. (1969) A respiratory virus study in Great Britain: Review and evaluation. Progress in Medical Virology, 11, Parainfluenza Viruses, p.374.

Jacobs, J.W., Peacock, D.B., Corner, B.D., Caul, E.O. \& ClaRKe, S.K.R. (1971) Respiratory syncytial and other viruses associated with respiratory disease in infants. Lancet, i, 871.

Medical Research Council Working Party on Acute RESPIRATORY VIRUS INFECTIONS (1965) A collaborative study of the aetiology of acute respiratory infections in Britain, 1961-4. British Medical Journal, 2, 319. 
Monto, A.S. \& Cavallaro, J.J. (1971) The Tecumseh study of respiratory illness. II. Patterns of occurrence of infection with respiratory pathogens, 1965-1969. American Journal of Epidemiology, 94, 280.

Mufson, M.A., Krause, H.E., Mocega, H.E. \& Dawson, F.W. (1970) Viruses, Mycoplasma pneumoniae, and bacteria associated with lower respiratory tract disease among infants. American Journal of Epidemiology, 91, 192.

Public Health Laboratory Service (1973) Parainfluenza type 1 virus. British Medical Journal, 1, 183.

Stark, J.E., Heath, R.B. \& Peto, S. (1964) A study of the antibodies against parainfluenza viruses in children's sera. Archiv für die Gesamte Virusforschung, 14, 160.

TAYLOR-Robinson, D. \& BYNOE, M.L. (1963) Parainfluenza 2 virus infections in adult volunteers. Journal of Hygiene, 61, 407.
Toвin, J.O'H. (1968) Discussion: epidemiology. Journal Clinical Pathology, 21, Supplement 2, 35.

Tyrrell, D.A.J. \& Bynoe, M.L. (1969) Studies on parainfluenza type 2 and 4 viruses obtained from patients with common colds. British Medical Journal, 1, 471.

Tyrrell, D.A.J., Bynoe, M.L., Petersen, K.B., Sutton, R.N.P. \& Pereira, M.S. (1959) Inoculation of human volunteers with parainfluenza viruses types 1 and 3. British Medical Journal, 4, 909.

Zakstelskaya, L.J., Arnaudova, V.I. \& Yakhno, M.A. (1969) Humoral immunity factors to parainfluenza viruses type 1,2 and 3 in infants under the age of one year. Journal of Hygiene, Epidemiology, Microbiology and Immunology, 13, 293. 